Agro-Science Journal of Tropical Agriculture, Food, Environment and Extension Volume 15 Number 2 May 2016 pp. $15-22$

ISSN 1119-7455

\title{
CHARACTERIZATION AND PRELIMINARY EVALUATION OF LOCAL GERMPLASM OF Telfairia occidentalis HOOK F. ACCESSIONS IN ENUGU, NIGERIA
}

\author{
Chukwudi*, U.P. and Agbo, C.U. \\ Department of Crop Science, University of Nigeria, Nsukka, Nigeria \\ *corresponding author's email: uchechukwu.chukwudi@unn.edu.ng
}

\begin{abstract}
The variability among 18 accessions of Telfairia occidentalis were studied by examining their yield and yield component traits. The 18 accessions were collected from four local government areas in Enugu State, Nigeria. The experiment was performed in a randomized complete block design replicated three times. Ih-M accession gave the highest fruit circumference and average fruit weight that was significantly higher than Ih-L accession. Ib-S accession gave the highest total fruit weight and number of fruits per hectare. The PCA result showed that the first three principal components explained $86.91 \%$ of the total variation. The dendrogram grouped the fluted pumpkin accessions into three major clusters at similarity coefficient of 0.80 . The cluster means showed that cluster I gave the highest number of days to first male anthesis and number of leaves per vine length of $40 \mathrm{~cm}$. Cluster II gave the shortest number of days to male and female anthesis. It gave the highest total marketable leaf yield, number and length of the vine, width and length of the terminal leaflet. Cluster III gave the highest total and average fruit weights, number of fruits, fruit length and circumference, vine diameter, number of leaves per plant, fresh and dry leaf:vine ratio. The results indicated that the reproductive and yield traits assessed had significant contributions towards fluted pumpkin diversity. This information is vital for conservation of different genetic materials and initiation of improvement programme for T. occidentalis in Nigeria.
\end{abstract}

Key words: accession, germplasm, principal component, Telfairia, yield

\section{INTRODUCTION}

Fluted pumpkin (Telfairia occidentalis Hook F.) is a leafy vegetable in the Cucurbitaceae family. Old plants regenerate from rootstocks left in the ground after total or partial shoot senescence at the end of a previous season (Akoroda et al., 2006) signifying a non-obligatory perennial plant.

Fluted pumpkin is an important vegetable supplement in the carbohydrate dominated staple food chain of West Africa, particularly Nigeria (Chukwudi and Agbo, 2014). The leaf is a rich source of protein, oil, vitamins and minerals (Idris, 2011) that can reduce blood glucose level (Salman et al., 2008) while the seed is a good source of edible oil that contains unsaturated fatty acids like oleic and linoleic acids including eicosapentaenoic acid (Bello et al., 2011). A low dose of $400 \mathrm{mg} / \mathrm{kg}$ body weight fluted pumpkin seed oil improved sperm count and testicular histology in rat (Akang et al., 2010). The tender vines, leaves and seeds are consumed by humans, while the mature vines constitute an important fiber source in animal diet (Chukwudi and Agbo, 2014). In addition to its health benefits and contribution to food security in sub-Saharan Africa, production of fluted pumpkin is an important economic activity and the means of livelihood of many rural communities (Ajayi et al., 2007; Odiaka et al., 2008; Chukwudi and Agbo, 2014).

Fluted pumpkin is indigenous to Nigeria, where many of its varying polyploids had been identified (Uguru and Onovo, 2011). It is grown in tropical wet coastal areas of West Africa, mainly in Benin, Cameroon, Ghana, Nigeria and Sierra Leone. It is also grown as a summer vegetable as far north as Florida (Ajayi et al., 2007). The all-year-round availability of fluted pumpkin did not signal early enough the systematic genetic erosion that has occurred over time (Ajayi et al., 2007).

There are over 205 endemic plant species in Nigeria with about 128 of the species localized in the eastern region (FAO, 1996). A regional stakeholder workshop for West Africa held in 2010, in Cotonou, Benin categorized fluted pumpkin among the neglected and underutilized plant species with the potential to play key role in supporting rural livelihoods and in alleviating the effects of biotic and abiotic stresses - particularly those related to climate change (RUFORUM, 2010).

The genetic diversity in germplasm resources constitute the building blocks of crop improvement 


\section{Characterization and Preliminary Evaluation of Germplasm of Telfairia occidentalis Accessions 16}

programme because they provide basic raw material and reservoir of genes for breeding high yielding and disease resistant cultivars (Singh and Sharma, 2007; Ferguson, 2007). Plant genetic resources form the basis of dynamic, diverse and adaptable agriculture; they are fundamental to national food security thus their conservation and utilization must be part of any developmental strategy if the nation aims to achieve self-sufficiency (FAO, 1996). Hence, it is important to identify and conserve the available germplasm for agricultural sustainability in Nigeria.

Plant breeders are under increasing pressure to improve yield without degrading the environment and ensuring biodiversity. Hence, the breeder needs genetic diversity to exploit heterosis and to develop composite varieties to satisfy different markets and climatic needs. Seed storage, field gene banks, botanical gardens, in vitro, pollen and DNA storage are some methods used to conserve plant genetic resources ex situ (Rao, 2001). The exploitation of genetic resources has over the years contributed significantly in the development of agriculture especially in the area of food crops like Zea mays, Vigna unguiculata, Oryza sativa and Manihot esculenta (FAO, 1996) but little effort had been made to characterize and conserve the biodiversity in Telfairia occidentalis. This study, therefore, was initiated to evaluate the variability among Telfairia occidentalis accessions collected in Enugu State, Nigeria by examining their yield and yield component traits in order to characterize them.

\section{MATERIALS AND METHODS}

Eighteen accessions of $T$. occidentalis (Ob-L, Ob-M, Ob-S, Ih-L, Ih-M, Ih-S, Or-L, Or-M, Or-S, Ib-L, IbM, Ib-S, Og-L, Og-M, Og-S, Oz-L, Oz-M, and Oz-S) were evaluated at the Research Farm of the Department of Crop Science, University of Nigeria, Nsukka (07 $29^{\prime} \mathrm{N}, 06^{\circ}$ 51' E; $400 \mathrm{~m}$ asl). The experiment was carried out in a randomized complete block design replicated three times. The accessions were collected from four local government areas (LGA) in Enugu State where the vegetable is densely cultivated in the state. Enugu State is in the Derived Savannah ecology. The names of the accessions were coined from town of collection and fruit size: $\mathrm{Ob}$ for Obukpa in Nsukka LGA, Ih for Iheaka in Igbo-Eze South LGA, Or for Orba in Udenu LGA, Ib for Ibagwa-aka in Igbo-Eze South LGA, Og for Ogbede in Igbo-Etiti LGA, and $\mathrm{Oz}$ for Ozalla in Igbo-Etiti LGA; L for large, $\mathrm{M}$ for medium, and $\mathrm{S}$ for small. Three fruits were collected per accession.

The experimental field measuring $875 \mathrm{~m}^{2}$ was cleared, ploughed, harrowed and marked out into three blocks. Each block was divided into 18 plots, each measuring $4 \mathrm{~m} \times 3 \mathrm{~m}\left(12 \mathrm{~m}^{2}\right)$. A distance of $1 \mathrm{~m}$ and $0.5 \mathrm{~m}$ was allowed between blocks and plots, respectively. Seeds were germinated on nursery media containing topsoil, poultry manure and river sand in the ratio of 3:2:1 by volume. Two weeks after emergence, the seedlings were transplanted at a plant spacing of $1 \mathrm{~m} \times 1 \mathrm{~m}$ to give 12 seedlings per plot.

Decomposed pig dung (20 t/ha) was incorporated into the soil two weeks before transplanting and NPK $15: 15: 15$ fertilizer $(750 \mathrm{~kg} / \mathrm{ha}$ split $)$ was applied at 4 and 10 weeks after transplanting (WAT). Weeding was manually done and no pesticide was used as the pest population did not reach economic threshold.

The following data were collected bi-weekly starting from $3^{\text {rd }}$ WAT to $9^{\text {th }}$ WAT on three plants per plot at the vegetative stage: vine diameter, number of leaves per vine length of $40 \mathrm{~cm}$, vine length, number of leaves and vines per plant, width of the terminal leaflet, total leaf yield (weight), fresh leaf and vine weight, dry leaf and vine weight. The leaf yields were weighed immediately after harvest before separating them into leaf and vine. The separated fresh leaves and vines were weighed to obtain their individual fresh weights. Each part was oven dried to a constant weight to obtain its dry weight. The fresh and dry weights were used to calculate the fresh and dry leafvine ratio. The bi-weekly leaf weights were summed to get the total leaf yield (weight). A micrometer screw gauge (Outside (C) Micrometer, Nigeria) was used to measure the vine diameter while flexible metric tape was used to measure the vine length and width of the terminal leaflet. The number of vines and leaves per plant were visually counted.

Each accession was monitored to obtain the number of days it took for the first male and female flowers to open (anthesis). At the end of the experiment, the total number of fruits per accession were counted and weighed to obtain the total fruit number and weight. The average fruit weight was determined by dividing the total fruit weight by the total number of fruits. The average fruit circumference and length were determined by finding the mean of the measured individual fruit circumference and length. The experiment was carried out in 2011 and repeated in 2012.

\section{Statistical Analysis}

The data collected were pooled and subjected to analysis of variance (ANOVA) and hierarchical clustering based on squared Euclidean distances according to Ward's method using GenStat Release 10.3 Discovery Edition (2011) statistical software. The means were compared using Fisher's least significant difference (F-LSD) as described by Obi (2002). Principal component analysis (PCA) and Principal coordinate analysis (PCoA) were carried out using GenStat to identify variations among the accessions and further confirm their classification. 


\section{RESULTS}

Oz-M accession gave the largest vine diameter at 3 WAT that was significantly different from the other accessions except Oz-L, Ih-L, Ih-M, Ib-L and Ob-S accessions (Table 1). Oz-M, Oz-L and Ih-L accessions had the largest vine diameter at 5 WAT that were significantly higher than $\mathrm{Ib}-\mathrm{S}$ accession. The lowest vine diameters at 3, 5, 7 and 9 WAT were recorded in $\mathrm{Og}-\mathrm{S}, \mathrm{Ib}-\mathrm{S}, \mathrm{Ob}-\mathrm{L}$ and $\mathrm{Ih}-\mathrm{S}$ accessions, respectively.

Ih- $\mathrm{L}$ accession produced the longest vine that was significantly higher than the other accessions at 3 WAT while at 5 WAT, Og-M accession had the longest vine that was significantly higher than $\mathrm{Ib}-\mathrm{S}$, Ih-L, Ih-S, Ob-M, Og-L, Og-S, Or-S and Oz-M accessions. At 9 WAT, Ob-S accession produced the longest vine that was significantly higher than some of the other accessions. Ib-S accession produced the shortest vine at 3 WAT while Og-L and Oz-M accessions gave the shortest vine length at 5 WAT.

Ih-M accession produced the highest number of vines per plant that was statistically similar to $\mathrm{Ib}-\mathrm{L}$, Ob-L, Oz-L, Og-M and Ib-S accessions but significantly higher than the other accessions at 3 WAT. At 5 and 9 WAT, Ob-L gave the highest value for vine diameter that was significantly higher than most of the accessions.

$\mathrm{Ob}-\mathrm{L}$ accession had the highest number of leaves per plant at 3, 5 and 7 WAT (Table 2). At 3 and 5 WAT, it was significantly higher than the other accessions except Ib-L and Og-M; Og-S and Og-M accessions, respectively. $\mathrm{Og}-\mathrm{S}$ accession gave the highest number of leaves plant ${ }^{-1}$ at 9 WAT that was significantly higher than Ib-L, Ib-M, Ih-L, Ih-M, Ih$\mathrm{S}$, Ob-M, Og-L, Or-M, Or-S, Oz-M and Oz-S accessions. The lowest number of leaves per plant at 3 WAT was obtained from Oz-S accession while at 5, 7 and 9 WAT, it was obtained from Ih-L accession.

The widest terminal leaflet was observed from Ih-L accession at 3 WAT. This was siginificantly higher than the other accessions with the exception of Or-L, Ob-S and Or-M accessions. Ib-M accession produced the widest terminal leaflet that was significantly higher than some of the accessions at 5, 7 and 9 WAT. Accessions Oz-S and Ob-L gave the least width of the terminal leaflets at 3 and 9 WAT, respectively. Ih-S accession produced the lowest width of the terminal leaflet at 5 and 7 WAT.

Figure 1 reveals that vine diameter had an initial increment of $12.8 \%$ between 3 and 5 WAT followed by $16.9 \%$ increase from 5 to 7 WAT. The vine length increased by $28.1 \%$ from 3 to 5 WAT; $37.5 \%$ from 5 to $7 \mathrm{WAT}$ and $7.3 \% 7$ to $9 \mathrm{WAT}$. However, there was a decremental increase of $2.8 \%$ from 7 to 9 WAT. Number of vines per plant, number of leaves per plant and width of the terminal leaflet had an initial growth of 49,77 and $24.9 \%$ respectively, from 3 to 5 WAT. Subsequently, they all had decremental increases each in the remaining weeks under study.
Oz-L accession was significantly $(P<0.05)$ higher than the other accessions in fresh weight ratio at 3 WAT with the exception of $\mathrm{Og}-\mathrm{L}$ and $\mathrm{Og}-\mathrm{S}$ (Table 3$)$. It was also significantly $(P<0.05)$ higher than $\mathrm{Ob}-\mathrm{L}$ at 5 WAT. At 7 and 9 WAT, Og-L was significantly $(P<0.05)$ higher in fresh weight ratio than most of the others. Oz-L was significantly $(P<$ $0.05)$ higher than the other accessions in dry weight ratio at 3 WAT with the exception of Og-L, Og-S, Or-L and Or-S, respectively. Og-L was significantly $(P<0.05)$ higher in dry weight ratio than some of the accessions at 5 and 7 WAT.

Generally, the average leaf: vine ratio on fresh and dry bases at 3 WAT were highest (Figure 2). There was $35.3 \%$ reduction from 3 to 5 WAT; $30.8 \%$ reduction from 5 to $7 \mathrm{WAT}$ and $7.5 \%$ reduction from 7 to 9 WAT on fresh weight basis. Also, on dry weight basis, there was $32.7 \%$ decrease from 3 to 5 WAT and $13.9 \%$ reduction from 7 to 9 WAT.

Ih-M accession gave the highest fruit circumference and average fruit weight that was significantly higher than Ih-L accession (Table 4). Ib$\mathrm{S}$ accession gave the highest total fruit weight of $25.60 \mathrm{t} /$ ha which was significantly higher than Ih-S, $\mathrm{Ob}-\mathrm{S}, \mathrm{Ib}-\mathrm{L}$, Ih-L, Ob-L and Oz-L accessions. It also produced the highest number of fruits per hectare that was significantly higher than Ih-S, Ib-L, Ob-L and $\mathrm{Oz}-\mathrm{L}$ accessions. Ob-S accession was significantly $(\mathrm{P}<0.05)$ higher in total leaf yield hectare ${ }^{-1}$ than the other accessions with the exception of Og-S, Ih-M, Og-M, Or-M, Ob-L, Og-L, Or-L and Oz-L accession.

To evaluate the patterns of variation in germplasm, Principal component analysis was done by simultaneously considering all 18 variables. The Principal component analysis showed that the first three principal components explained $86.91 \%$ of the total variation in the $18 \mathrm{~T}$. occidentalis accessions using 17 traits (Table 5). The principal component axes $1\left(\mathrm{PCA}_{1}\right)$ accounted for $57.25 \%$ of the total variation while the $\mathrm{PCA}_{2}$ accounted for $19.35 \%$ of the variation unaccounted for by the first principal axis. The $\mathrm{PCA}_{3}$ explained $10.31 \%$ of the variation unaccounted for by $\mathrm{PCA}_{1}$ and $\mathrm{PCA}_{2}$.

The traits affecting the first principal component axis were vine length, days to male flower anthesis and days to female flower anthesis. Fruit length, days to male and female anthesis were the traits with the largest positive coefficients, while vine length and number of leaves per plant had the largest negative coefficients along the first principal component axis.

The second principal component accounted mainly for the patterns of variation in total fruit weight and fruit circumference. Days to male and female anthesis, total fruit weight, total number of fruits, fruit circumference, total leaf yield, vine length width and length of the terminal leaflet contributed positively towards third principal component. 
Characterization and Preliminary Evaluation of Germplasm of Telfairia occidentalis Accessions 18

Table 1: Performance evaluation of vine traits of T. occidentalis accession from 3 to 9 WAT

\begin{tabular}{|c|c|c|c|c|c|c|c|c|c|c|c|c|}
\hline \multirow{2}{*}{ Accessions } & \multicolumn{4}{|c|}{ Vine diameter (mm) } & \multicolumn{4}{|c|}{ Vine Length $(\mathrm{cm})$} & \multicolumn{4}{|c|}{ Number of vines per plant } \\
\hline & $3 \mathrm{WAT}$ & $5 \mathrm{WAT}$ & 7WAT & 9WAT & 3WAT & 5WAT & 7WAT & 9WAT & $3 \mathrm{WAT}$ & 5WAT & 7WAT & 9WAT \\
\hline Ib-L & 5.8 & 6.4 & 6.6 & 6.8 & 59.0 & 66.3 & 95.3 & 61.8 & 2.8 & 3.3 & 3.5 & 2.7 \\
\hline Ib-M & 5.4 & 6.0 & 7.1 & 7.5 & 34.2 & 64.0 & 86.7 & 108.5 & 1.7 & 2.5 & 3.8 & 3.5 \\
\hline Ib-S & 4.6 & 5.0 & 6.4 & 7.0 & 30.0 & 51.3 & 78.2 & 87.7 & 2.5 & 3.3 & 5.0 & 5.7 \\
\hline Ih-L & 6.2 & 6.8 & 8.0 & 7.3 & 72.5 & 55.8 & 65.5 & 79.0 & 1.3 & 2.2 & 3.3 & 3.5 \\
\hline Ih-M & 6.2 & 6.5 & 8.0 & 7.9 & 57.7 & 77.2 & 90.7 & 94.3 & 3.0 & 3.3 & 3.5 & 3.0 \\
\hline Ih-S & 4.6 & 5.4 & 6.5 & 6.3 & 43.3 & 43.0 & 72.0 & 72.0 & 1.7 & 2.5 & 2.5 & 3.2 \\
\hline Ob-L & 5.0 & 6.2 & 6.3 & 7.0 & 53.7 & 76.7 & 83.7 & 82.3 & 2.8 & 4.2 & 4.3 & 6.3 \\
\hline Ob-M & 4.7 & 5.7 & 6.8 & 7.2 & 38.3 & 43.3 & 89.7 & 84.5 & 1.3 & 2.3 & 3.2 & 4.3 \\
\hline $\mathrm{Ob}-\mathrm{S}$ & 5.7 & 6.0 & 6.9 & 7.1 & 53.2 & 65.5 & 89.8 & 122.0 & 1.7 & 3.2 & 4.3 & 5.0 \\
\hline Og-L & 5.2 & 5.6 & 6.9 & 7.2 & 43.0 & 42.8 & 70.0 & 80.3 & 1.3 & 2.7 & 3.8 & 4.3 \\
\hline Og-M & 5.6 & 6.1 & 7.4 & 7.3 & 43.8 & 79.8 & 79.3 & 106.7 & 2.7 & 3.0 & 4.5 & 5.0 \\
\hline $\mathrm{Og}_{-} \mathrm{S}$ & 4.1 & 6.1 & 7.8 & 7.9 & 37.3 & 47.0 & 64.7 & 77.7 & 1.8 & 3.7 & 4.2 & 4.7 \\
\hline Or-L & 5.4 & 6.3 & 7.1 & 7.7 & 55.5 & 78.0 & 84.0 & 83.7 & 1.8 & 2.7 & 3.3 & 3.8 \\
\hline Or-M & 5.5 & 6.5 & 7.7 & 7.1 & 55.8 & 67.2 & 79.7 & 85.3 & 1.5 & 2.3 & 2.7 & 3.0 \\
\hline Or-S & 4.6 & 5.6 & 7.4 & 7.5 & 33.2 & 49.5 & 79.7 & 81.7 & 1.5 & 2.3 & 4.7 & 4.3 \\
\hline Oz-L & 6.2 & 6.8 & 7.2 & 7.5 & 40.2 & 58.7 & 84.5 & 93.2 & 2.8 & 3.2 & 4.5 & 5.5 \\
\hline Oz-M & 6.8 & 6.8 & 7.0 & 8.2 & 44.2 & 42.8 & 86.5 & 85.5 & 1.2 & 2.3 & 3.5 & 3.8 \\
\hline Oz-S & 5.2 & 5.4 & 6.6 & 6.8 & 37.0 & 56.8 & 85.3 & 86.7 & 1.5 & 3.0 & 3.5 & 3.5 \\
\hline $\operatorname{LSD}_{(0.05)}$ & 1.1 & 1.4 & 1.6 & 1.3 & 9.9 & 23.2 & ns & 30.2 & 1.0 & 0.9 & 1.1 & 1.6 \\
\hline
\end{tabular}

WAT $=$ Weeks after transplanting; ns = non-significant

Table 2: Number of leaves and width of terminal leaflet of T. occidentalis accessions during 3-9 WAT

\begin{tabular}{|c|c|c|c|c|c|c|c|c|}
\hline \multirow{2}{*}{ Accessions } & \multicolumn{4}{|c|}{ Number of leaves per plant } & \multicolumn{4}{|c|}{ Width of terminal leaflet $(\mathrm{cm})$} \\
\hline & $3 \mathrm{WAT}$ & $5 \mathrm{WAT}$ & $7 \mathrm{WAT}$ & $9 \mathrm{WAT}$ & 3 WAT & $5 \mathrm{WAT}$ & 7 WAT & 9 WAT \\
\hline Ib-L & 24.3 & 34.2 & 45.0 & 40.3 & 4.1 & 4.9 & 4.7 & 5.4 \\
\hline Ib-M & 14.3 & 24.7 & 41.5 & 44.2 & 4.0 & 6.9 & 7.1 & 7.6 \\
\hline Ib-S & 17.3 & 33.5 & 47.3 & 60.7 & 3.7 & 4.6 & 6.4 & 6.1 \\
\hline Ih-L & 14.5 & 17.8 & 25.3 & 33.7 & 5.6 & 5.6 & 6.6 & 6.0 \\
\hline Ih-M & 23.0 & 39.8 & 42.0 & 44.8 & 4.7 & 5.5 & 5.0 & 5.8 \\
\hline Ih-S & 14.0 & 22.5 & 25.8 & 37.8 & 3.7 & 3.9 & 4.7 & 5.4 \\
\hline $\mathrm{Ob}-\mathrm{L}$ & 27.0 & 50.2 & 58.8 & 54.7 & 4.5 & 4.7 & 5.6 & 5.1 \\
\hline Ob-M & 14.2 & 22.7 & 33.3 & 45.2 & 4.1 & 4.9 & 6.5 & 7.0 \\
\hline Ob-S & 15.7 & 31.8 & 46.7 & 54.5 & 5.0 & 5.5 & 6.3 & 7.4 \\
\hline Og-L & 14.2 & 25.2 & 41.3 & 47.3 & 4.6 & 6.2 & 7.0 & 7.4 \\
\hline Og-M & 23.8 & 46.3 & 55.8 & 64.0 & 4.6 & 5.9 & 6.4 & 7.0 \\
\hline Og-S & 16.8 & 41.3 & 51.5 & 67.2 & 4.2 & 5.2 & 5.9 & 7.3 \\
\hline Or-L & 18.0 & 28.8 & 39.7 & 46.8 & 5.2 & 6.5 & 6.3 & 7.5 \\
\hline Or-M & 16.5 & 27.2 & 36.5 & 40.0 & 5.0 & 6.4 & 6.1 & 6.6 \\
\hline Or-S & 14.5 & 28.5 & 47.3 & 51.3 & 4.1 & 5.8 & 6.3 & 6.2 \\
\hline Oz-L & 20.7 & 33.3 & 49.3 & 56.7 & 4.6 & 5.4 & 7.0 & 6.3 \\
\hline Oz-M & 13.5 & 22.7 & 38.8 & 46.0 & 3.9 & 4.9 & 6.4 & 6.3 \\
\hline Oz-S & 13.0 & 27.5 & 40.3 & 38.8 & 3.6 & 6.1 & 7.0 & 7.1 \\
\hline F-LSD $_{(0.05)}$ & 3.9 & 9.8 & 13.7 & 15.0 & 0.8 & 1.4 & 1.4 & 1.6 \\
\hline
\end{tabular}

WAT $=$ Weeks after Transplanting

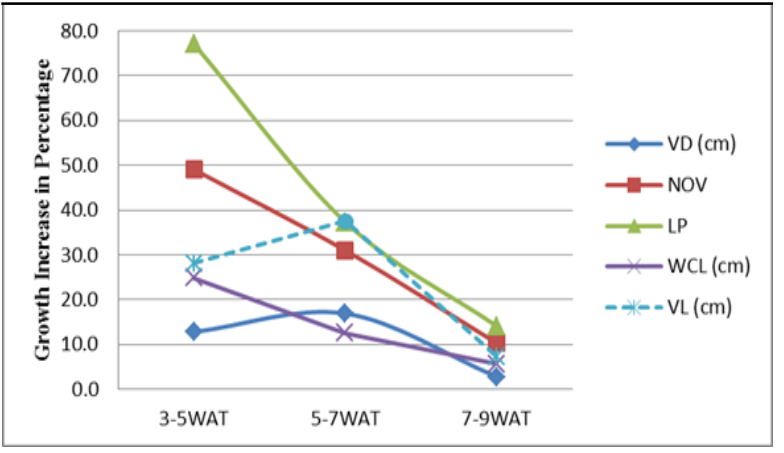

WAT $=$ Weeks after Transplanting, $\mathrm{VD}=$ vine diameter, $\mathrm{NOV}=$ no. of vines per plant, $\mathrm{LP}=$ no. of leaves per plant, $\mathrm{WCL}=$ width of terminal leaflet and $\mathrm{VL}=$ Vine length

Figure 1: Average growth increase (\%) in leaf and vine parameters of $T$. occidentalis accessions over 9 WAT

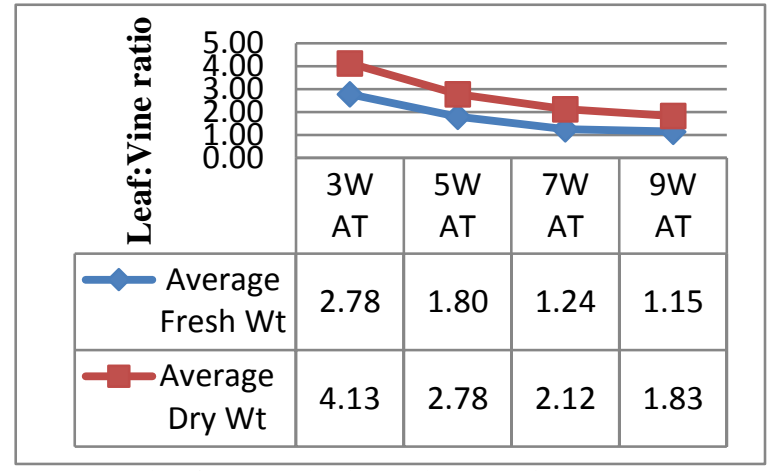

$\mathrm{WAT}=$ weeks after transplanting and $\mathrm{Wt}=$ weight

Figure 2: Leaf:vine ratio pattern in 18 accessions of T. occidentalis at vegetative stage 
Table 3: Effect of Accession on the leaf-vine ratio of T. occidentalis

\begin{tabular}{|c|c|c|c|c|c|c|c|c|}
\hline \multirow[b]{2}{*}{ Accessions } & \multicolumn{4}{|c|}{ Fresh weight } & \multicolumn{4}{|c|}{ Dry weight } \\
\hline & 3 WAT & $5 \mathrm{WAT}$ & $7 \mathrm{WAT}$ & 9 WAT & 3 WAT & 5 WAT & 7 WAT & $9 \mathrm{WAT}$ \\
\hline Ib-L & 2.01 & 1.74 & 0.97 & 1.20 & 3.11 & 2.87 & 1.61 & 2.15 \\
\hline Ib-M & 2.44 & 1.95 & 1.27 & 1.23 & 3.46 & 2.61 & 2.37 & 1.90 \\
\hline Ib-S & 2.42 & 1.93 & 1.47 & 1.29 & 3.91 & 2.93 & 2.32 & 1.96 \\
\hline Ih-L & 2.32 & 1.80 & 1.00 & 0.92 & 3.55 & 3.07 & 1.56 & 1.41 \\
\hline Ih-M & 2.46 & 1.53 & 1.08 & 1.06 & 3.96 & 2.40 & 1.93 & 1.71 \\
\hline Ih-S & 2.44 & 1.94 & 1.59 & 1.27 & 4.01 & 2.66 & 2.70 & 2.24 \\
\hline Ob-L & 2.45 & 1.37 & 1.00 & 1.00 & 3.39 & 2.29 & 1.68 & 1.55 \\
\hline Ob-M & 2.94 & 1.77 & 1.12 & 1.16 & 4.37 & 3.23 & 1.80 & 1.84 \\
\hline $\mathrm{Ob}-\mathrm{S}$ & 2.59 & 1.63 & 1.04 & 1.06 & 3.97 & 2.45 & 1.81 & 1.63 \\
\hline Og-L & 3.72 & 1.98 & 1.70 & 1.40 & 5.36 & 3.33 & 2.95 & 2.14 \\
\hline Og-M & 3.08 & 1.64 & 1.31 & 1.12 & 4.55 & 2.60 & 2.22 & 1.75 \\
\hline Og-S & 3.34 & 2.07 & 1.40 & 1.18 & 4.21 & 3.05 & 2.28 & 1.73 \\
\hline Or-L & 2.95 & 1.93 & 1.40 & 1.37 & 3.93 & 2.90 & 2.53 & 2.10 \\
\hline Or-M & 2.65 & 1.64 & 1.02 & 0.80 & 3.93 & 2.49 & 1.93 & 1.37 \\
\hline Or-S & 2.86 & 2.07 & 1.35 & 1.35 & 4.88 & 2.61 & 2.32 & 2.18 \\
\hline $\mathrm{Oz}-\mathrm{L}$ & 4.03 & 2.12 & 1.38 & 1.31 & 6.12 & 3.30 & 2.24 & 1.96 \\
\hline Oz-M & 2.61 & 1.68 & 1.09 & 1.08 & 3.79 & 2.40 & 1.80 & 1.68 \\
\hline Oz-S & 2.72 & 1.59 & 1.21 & 0.92 & 3.77 & 2.77 & 2.11 & 1.56 \\
\hline F-LSD $(0.05)$ & 0.73 & 0.70 & 0.41 & 0.33 & 1.29 & 0.88 & 0.69 & 0.54 \\
\hline
\end{tabular}

WAT $=$ Weeks after transplanting

Table 4: Leaf and fruit yield parameters of $T$. occidentalis as influenced by accession

\begin{tabular}{|c|c|c|c|c|c|c|}
\hline Accessions & NFH & TFW & AFW & FC & FL & TLY \\
\hline & & $\left(\mathrm{t} \mathrm{ha}^{-1}\right)$ & $(\mathrm{kg})$ & (cm) & $(\mathrm{cm})$ & $\left(\mathrm{t} \mathrm{ha}^{-1}\right)$ \\
\hline Ib-L & 3750.0 & 7.78 & 2.16 & 53.50 & 32.50 & 1.16 \\
\hline Ib-M & 6250.0 & 16.17 & 2.43 & 53.91 & 30.02 & 1.69 \\
\hline Ib-S & 10000.0 & 25.60 & 3.10 & 56.58 & 36.06 & 1.86 \\
\hline Ih-L & 6250.0 & 10.27 & 1.61 & 45.51 & 30.58 & 1.62 \\
\hline Ih-M & 5417.0 & 14.67 & 3.31 & 60.91 & 33.69 & 2.00 \\
\hline Ih-S & 2917.0 & 6.25 & 2.35 & 54.93 & 34.67 & 0.59 \\
\hline Ob-L & 1667.0 & 4.30 & 2.69 & 55.58 & 36.00 & 2.19 \\
\hline Ob-M & 6250.0 & 16.81 & 2.54 & 55.56 & 32.93 & 1.79 \\
\hline $\mathrm{Ob}-\mathrm{S}$ & 4583.0 & 9.88 & 2.12 & 52.22 & 31.44 & 2.64 \\
\hline Og-L & 6250.0 & 17.27 & 2.54 & 52.89 & 36.06 & 2.40 \\
\hline Og-M & 9167.0 & 25.23 & 2.70 & 55.95 & 30.73 & 2.55 \\
\hline $\mathrm{Og}-\mathrm{S}$ & 6250.0 & 17.79 & 3.04 & 55.40 & 31.90 & 1.97 \\
\hline Or-L & 9167.0 & 23.05 & 2.66 & 53.74 & 32.42 & 2.31 \\
\hline Or-M & 7083.0 & 14.46 & 2.07 & 52.32 & 30.03 & 2.30 \\
\hline Or-S & 7917.0 & 22.96 & 2.86 & 55.56 & 33.98 & 1.11 \\
\hline Oz-L & 3750.0 & 11.08 & 3.00 & 59.28 & 34.83 & 2.06 \\
\hline Oz-M & 5833.0 & 14.29 & 2.74 & 52.58 & 33.04 & 1.69 \\
\hline $\mathrm{Oz}-\mathrm{S}$ & 7083.0 & 14.06 & 2.29 & 53.56 & 30.06 & 1.86 \\
\hline F-LSD $(0.05)$ & 5646.4 & 12.86 & 1.34 & 10.61 & $\mathrm{~ns}$ & 0.68 \\
\hline
\end{tabular}

$\mathrm{NFH}$ - number of fruits per hectare, TFWH - total fruit weight per hectare

$\left(\mathrm{t} \mathrm{ha}^{-1}\right), \mathrm{AFW}$ - average fruit weight $(\mathrm{kg}), \mathrm{FC}$ - fruit circumference $(\mathrm{cm}), \mathrm{FL}$ - fruit length, TLY - total leaf yield, ns - non-significant

The second principal component accounted mainly for the patterns of variation in total fruit weight and fruit circumference. Days to male and female anthesis, total fruit weight, total number of fruits, fruit circumference, total leaf yield, vine length width and length of the terminal leaflet contributed positively towards third principal component.

Principal coordinate analysis (PCoA) was performed to understand the association among the pumpkin accessions in greater detail (Figure 3). The results of PCoA analysis showed three clusters as accounted for by the first and second principal axes. The clusters corresponded to those obtained through dendrogram. The dendrogram grouped the accessions into three major clusters at similarity coefficient of
0.80 (Figure 4). Cluster I is comprised of Ib-L, Ih-L, $\mathrm{Ob}-\mathrm{L}$ and Ih-S accessions. Cluster II is made up of $\mathrm{Ib}-\mathrm{M}$ and $\mathrm{Ob}-\mathrm{S}$ accessions. Ib-S, Og-L, Og-M, Og-S, Or-L, Or-S, Ih-M, Oz-M, Oz-L, Ob-M, Oz-S and Or$\mathrm{M}$ accessions were grouped into cluster III.

The cluster means showed that cluster I performed below average in total marketable leaf yield, total number and weight of fruits per hectare and all the other traits except number of days for first male anthesis and number of leaves per vine length of $40 \mathrm{~cm}$; where it produced the highest means (Table 6). Cluster II gave the shortest number of days to male and female anthesis and the lowest number of leaves per vine length of $40 \mathrm{~cm}$. It gave the highest total marketable leaf yield, number and length of the 
Characterization and Preliminary Evaluation of Germplasm of Telfairia occidentalis Accessions 20

Table 5: Percentage variation and latent loading of the principal component axes of pumpkin accessions

\begin{tabular}{lrrr}
\hline Plant Traits & $\mathrm{PCA}_{1}$ & $\mathrm{PCA}_{2}$ & $\mathrm{PCA}_{3}$ \\
\hline $\begin{array}{l}\text { Days to male flower } \\
\text { anthesis }\end{array}$ & 0.47433 & -0.39002 & 0.56598 \\
$\begin{array}{l}\text { Days to female flower } \\
\text { anthesis }\end{array}$ & 0.31187 & -0.20524 & 0.28991 \\
Total fruit weight $\left(\mathrm{t} \mathrm{ha}{ }^{-1}\right.$ ) & -0.0469 & -0.32022 & 0.16742 \\
$\begin{array}{l}\text { Total number of fruits per } \\
\text { hectare }\end{array}$ & -0.01346 & -0.06683 & 0.07031 \\
Average fruit weight $(\mathrm{kg})$ & -0.00193 & -0.03997 & -0.01304 \\
Fruit circumference (cm) & -0.00835 & -0.23481 & 0.01079 \\
Fruit length (cm) & 0.0347 & -0.11592 & -0.12402 \\
Total leaf yield (t ha & $-1)$ \\
Number of leaves per plant & -0.01575 & -0.0199 & 0.02153 \\
Vine length (cm) & -0.78298 & -0.05371 & 0.57797 \\
$\begin{array}{l}\text { Number of leaves per } \\
\text { vine length of 40 cm }\end{array}$ & 0.01762 & -0.00002 & -0.02398 \\
$\begin{array}{l}\text { Width of terminal leaflet } \\
\text { (cm) }\end{array}$ & -0.02027 & -0.01618 & 0.04387 \\
$\begin{array}{l}\text { Length of terminal leaflet } \\
\text { (cm) }\end{array}$ & -0.03924 & -0.03561 & 0.04559 \\
Number of vines per plant & -0.0231 & -0.06021 & -0.0426 \\
Vine diameter (mm) & -0.00749 & -0.00917 & -0.01048 \\
$\begin{array}{l}\text { Fresh leaf vine ratio } \\
\text { @ 7 WAT }\end{array}$ & -0.00108 & -0.00879 & -0.00795 \\
$\begin{array}{l}\text { Dry leaf vine ratio } \\
\text { @ 7 WAT }\end{array}$ & 0.00026 & -0.00725 & -0.00791 \\
Percentage Variation & 57.25 & 19.35 & 10.31 \\
\hline
\end{tabular}

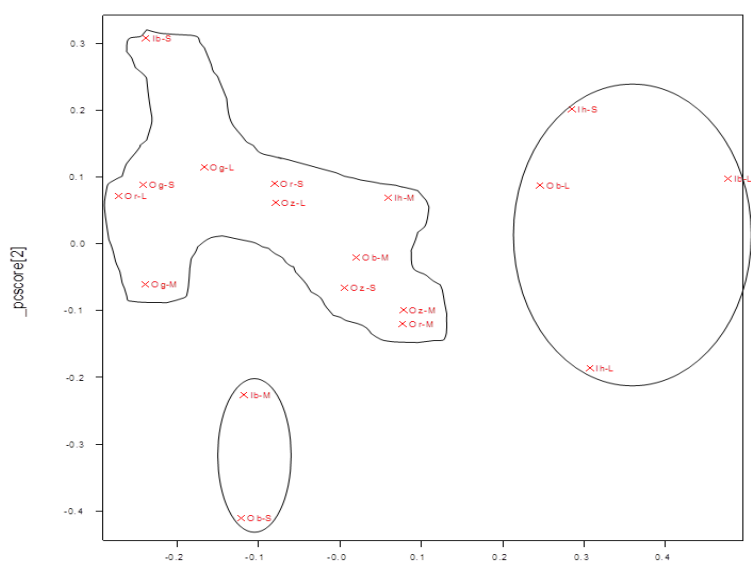

pcscore11

Figure 3: Plot of first- and second-component scores for 18 accessions of $T$. occidentalis

vine, width and length of the terminal leaflet and was above average in number of leaves per plant. Cluster II performed averagely in vine diameter, fresh and dry leaf:vine ratio but was below average in fruit circumference, fruit lenght, average and total fruit weight, and number of fruits.

Cluster III gave the highest total and average fruit weights, number of fruits, fruit length and circumference, vine diameter, number of leaves per
Table 6: Mean growth and yield traits for clusters (C) I, II and III in the 18 T. occidentalis accessions

\begin{tabular}{|c|c|c|c|c|}
\hline & C-I & C-II & C-III & Mean \\
\hline $\begin{array}{l}\text { Days to male } \\
\text { flower anthesis }\end{array}$ & 129.0 & 110.5 & 128.1 & 126.3 \\
\hline $\begin{array}{l}\text { Days to female } \\
\text { flower anthesis }\end{array}$ & 145.9 & 130.4 & 146.1 & 144.3 \\
\hline Total fruit weight ( $t / h a)$ & 7.1 & 12.9 & 17.7 & 14.8 \\
\hline $\begin{array}{l}\text { Total number of } \\
\text { fruits per hectare }\end{array}$ & 3542 & 5208.0 & 6319.0 & 5579.0 \\
\hline Average fruit weight $(\mathrm{kg})$ & 2.2 & 2.3 & 3.0 & 2.7 \\
\hline Fruit circumference $(\mathrm{cm})$ & 52.6 & 53.5 & 57.4 & 55.9 \\
\hline Fruit length $(\mathrm{cm})$ & 33.6 & 31.0 & 34.3 & 33.8 \\
\hline Total leaf yield (t/ha) & 1.4 & 2.2 & 2.0 & 1.9 \\
\hline $\begin{array}{l}\text { Number of leaves } \\
\text { per plant }\end{array}$ & 41.6 & 49.4 & 50.7 & 48.6 \\
\hline Vine length $(\mathrm{cm})$ & 73.8 & 115.3 & 87.3 & 87.4 \\
\hline $\begin{array}{l}\text { Number of leaves per } \\
\text { vine length of } 40 \mathrm{~cm}\end{array}$ & 5.5 & 4.2 & 4.9 & 5.0 \\
\hline $\begin{array}{l}\text { Width of terminal } \\
\text { leaflet }(\mathrm{cm})\end{array}$ & 5.5 & 7.5 & 6.7 & 6.5 \\
\hline $\begin{array}{l}\text { Length of terminal } \\
\text { leaflet }(\mathrm{cm})\end{array}$ & 9.7 & 12.8 & 11.8 & 11.5 \\
\hline $\begin{array}{l}\text { Number of vines } \\
\text { per plant }\end{array}$ & 3.9 & 4.3 & 4.2 & 4.2 \\
\hline Vine diameter (mm) & 6.8 & 7.3 & 7.4 & 7.3 \\
\hline $\begin{array}{l}\text { Fresh leaf vine ratio @ } \\
\text { 7WAT }\end{array}$ & 1.1 & 1.2 & 1.3 & 1.2 \\
\hline $\begin{array}{l}\text { Dry leaf vine ratio } \\
\text { @ } 7 \text { WAT }\end{array}$ & 1.9 & 2.1 & 2.2 & 2.1 \\
\hline
\end{tabular}

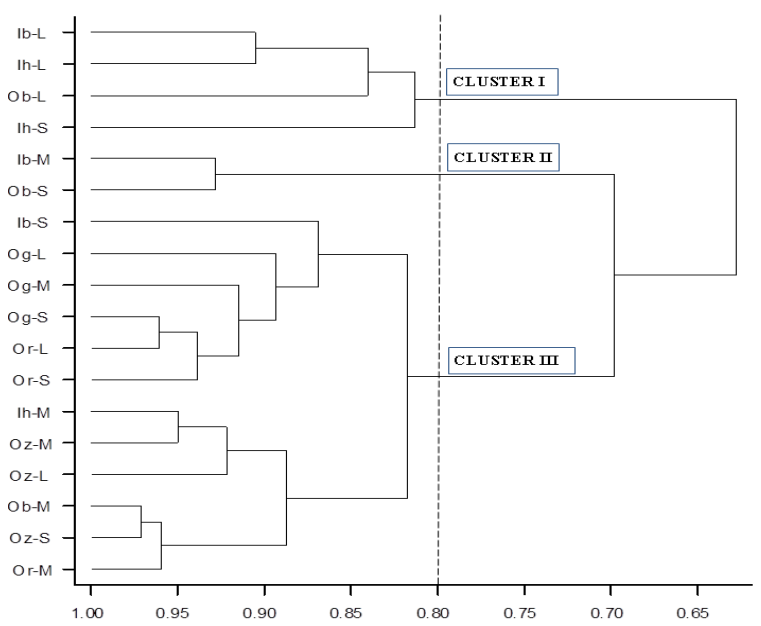

Figure 4: Dendrogram of the 18 accessions of $T$. occidentalis following Ward's method

plant, fresh and dry leaf:vine ratio. It performed above average in total marketable leaf yield, width and length of the terminal leaflet. Cluster III also gave an average performance with respect to number of vines per plant but performed below average in number of leaves per vine length of $40 \mathrm{~cm}$. However, it took the highest number of days for the female flower to open and above average number of days for the male flower to open. 


\section{DISCUSSION}

The initial high increase in width of the terminal leaflet, number of vines and leaves per plant at the early vegetative stage indicated a high photosynthates deposit in the leaves for leaf expansion and multiplication. The increase in number of branches after first harvest at 3 WAT was as a result of apical dominance removal which resulted in new branch flushes. Ogar and Asiegbu (2005) reported high leaf yield and number of branches in fluted pumpkin as a result of apical dominance removal. The reduced increase in these plant parts from 5 to 7 WAT suggested increased deposit in the vine portion which resulted in improved vine diameter and length.

Dry matter partitioning is the end result of the flow of assimilates from source organs through a transport path to the sink organs which are regulated by the sink strength (Marcelis and Heuvelink, 1999). The implication of higher dry weight leaf-vine ratio over the fresh weight ratio was that more moisture was contained in the vine at harvest. After the moisture removal through drying, the dry matter content of the leaves was revealed to be higher than the dry matter of the vine. The leaf-vine ratio over the weeks showed that fluted pumpkin apportioned more photosynthates to the leaf than the vine in its partitioning pattern. However, the trend changed as the plant aged with near equilibrium at 9 WAT. This indicated that fluted pumpkin at 7 WAT is still undergoing primary growth. The general decremental increase in the leaf and vine parameters measured at 9 WAT showed a gradual transition from vegetative growth phase to reproductive phase.

The range of days to female and male anthesis obtained in this study compared favourably with the result of Akoroda and Adejoro (1990) where female and male plants took about 150 and 129 days, respectively to flower; Odiaka and Akoroda (2009) where female plants commenced flowering from 105 to 141 days after sowing.

The genetic differences among the 18 accessions sourced from different locations were evident in the fruit and leaf yield parameters measured. Similar results had been reported by Fayeun et al. (2012) in fluted pumpkin. This study identified vine length, floral initiation, number of leaves per plant, fruit weight and circumference as traits that can be used to distinguish fluted pumpkin. These traits showed high loading in the first and second principal components and agrees with Odiaka et al. (2008) where fruit size, leaf size and thickness of vine were identified as genetic qualities that could be used as distinguishing characters in T. occidentalis.

Genetic diversity is required to exploit heterosis and to develop composite varieties that would match different market and climatic needs. The variation in among the accessions could be due to their genetic differences as they were maintained as landraces from their source of collection. Agbo (2010) reported diverse genetic base in clones of Utazi (Gongronema latifolia Benth.) from different localities in southeastern Nigeria. Ugese et al. (2008) also showed that source of seed of Shea butter (Vitellaria paradoxa Gaertn F.) had effect on most of its traits. Fayeun et al. (2012) reported variations in fresh leaf weight, vine weight, and marketable leaf yield of fluted pumpkin sourced from different locations.

The genetic diversity in Telfairia maintained by Enugu farmers as landraces may account for its fruit demand for propagation by Telfairia farmers outside the state. Odiaka et al. (2008) reported that Makurdi Telfairia farmers source their seeds from the south eastern states of Nigeria due to better yield in leaf production than seeds produced in Makurdi.

Plant collection is done to obtain natural variability that could be useful for providing germplasm pools for crop improvement (Manggoel and Uguru, 2011). The intra-population variability evaluated by cluster analyses conducted on the quantitative traits grouped the accessions into three major clusters indicating sufficient variability to warrant selection. The scatter plot of the first and second principal coordinate axes confirmed the three clusters delineated by the dendrogram. Three fluted pumpkin clusters were also identified by Odiaka (2005) in a population of nine accessions sourced from four localities.

Cluster I is characterized by prolonged male vegetative growth pattern with short internode distance. This trait is desired in breeding for leaf production because male $T$. occidentalis plants loss market value after flowering. The accessions in cluster II were early flowering with long vines and broad leaves. The possession of long vines and broad leaves by accessions in cluster II made them to be prolific in the production of marketable leaves. Aremu and Adewale (2012) associated broadness of leaf with increased yield in fluted pumpkin. Fluted pumpkin accessions in cluster III are high fruit yielders. These accessions possessed higher number of leaves per plant which was pivotal to its high fruit quality and quantity as more photosynthetic activities took place on the leaf surface resulting in more translocation of photosynthates to the fruits. Chukwudi and Agbo (2014) reported that leaf harvest into flowering/fruiting phase of fluted pumpkin reduces the fruit quality and quantity. These results indicated that the reproductive and yield traits assessed had significant contributions towards fluted pumpkin diversity. Cluster analysis has proved to be an effective method in grouping accessions (Shukla et al., 2009) which is important in maintaining their biodiversity and utilization in crop improvement programmes. 


\section{CONCLUSION}

The genetic differences that existed among the accessions from different locations were evident in the morphological growth parameters measured and the yield obtained. This study identified vine length, floral initiation, number of leaves per plant, fruit weight and circumference as traits that can be used to distinguish $T$. occidentalis. The results indicated that the reproductive and yield traits assessed had significant contributions towards fluted pumpkin diversity. This information is vital for conservation of different genetic materials and initiation of improvement programme for $T$. occidentalis in Nigeria. Further studies involving more accessions are recommended at molecular and genomic levels for a holistic characterization of $T$. occidentalis.

\section{REFERENCES}

Agbo, C.U. (2010). Genetic diversity in vegetative traits of Utazi (Gongronema latifolia Benth) grown for two cropping seasons in Nsukka. Journal of Crop Science and Biotechnology, 13 (3), 169-175

Ajayi, S.A., Dulloo, M.E., Vodouhe, R.S., Berjak, P. and Kioko, J.I. (2007). Conservation status of Telfairia spp. in sub-Saharan Africa. In: R. Vodouhe, K. Atta-Krah, G.E. Achigan-Dako et al. (Eds.), Plant Genetic Resources and Food Security in West and Central Africa (pp. 89-95). Regional Conference, Ibadan, Nigeria, 26-30 April, 2004

Akang, E.N., Oremosu, A.A., Dosumu, O.O., Noronha, C.C. and Okanlawon A.O. (2010). The effect of fluted pumpkin (Telfairia occidentalis) seed oil (FPSO) on testis and semen parameters. Agric. Biol. J. N. Am., 1 (4), 697-703

Akoroda, M.O. and Adejoro, M.A. (1990). Patterns of vegetative and sexual development of Telfairia occidentalis Hook. F. Trop. Agric. (Trinidad), 67 (3), 243-247

Akoroda, M.O., Ojeifo, I.M., Odiaka, N.I., Ugwo, O.E. and Fuwa, B. (2006).Vegetative structure of the perennating organs of Telfairia occidentalis. European Journal of Sci. Res., 14 (1), 6-20

Aremu, C.O. and Adewale, D.B. (2012). Origin and seed positional effect on sex ratio of Telfairia occidentalis Hook F. Grown in Savanna Agro-ecology. Int. J. Plant Breeding Genetics, 6, 32-39

Bello, M.O., Akindele, T.L., Adeoye, D.O. and Oladimeji, A.O. (2011). Physicochemical properties and fatty acids profile of seed oil of Telfairia occidentalis Hook F. Int. J. Basic \& Applied Sciences, 11 (6), 9-14

Chukwudi, U.P. and Agbo, C.U. (2014). Leaf and fruit yield performance of fluted pumpkin (Telfairia occidentalis Hook F.) as influenced by fruit size. Notulae Sci. Biol., 6 (4), 509-514

FAO (1996). Nigeria: Country report to the FAO International Technical Conference on Plant Genetic Resources, Leipzig, Germany, 17-23 June 1996.

Fayeun L.S., Odiyi, A.C., Makinde, S.C.O. and Aiyelari, O.P. (2012). Genetic variability and correlation studies in the fluted pumpkin (Telfairia occidentalis Hook F.). J. Plant Breeding Crop Sci., 4 (10), 156-160

Ferguson, A.R. (2007). The need for characterisation and evaluation of germplasm: kiwifruit as an example. Euphytica, 154 (3), 371-382
GenStat Release 10.3DE (2011). VSN International Ltd. (Rothamsted Experimental Station)

Idris, S. (2011). Compositional studies of Telfairia occidentalis leaves. Ameri. J. of Chem., 1 (2), 56-59

Manggoel, W. and Uguru, M.I. (2011). Comparative study on the phenology and yield components of two photoperiodic groups of cowpea (Vigna unguiculata (L.) Walp.) in two cropping seasons. African Journal of Agricultural Research, 6 (23), 5232-5241

Marcelis, L.F.M. and Heuvelink, E. (1999). Modelling fruit set, fruit growth and dry matter partitioning. Acta Hortic., 499, 39-50

Obi, I.U. (2002). Statistical methods of detecting difference between treatment means for field and laboratory experiments ( $2^{\text {nd }}$ ed.), AP Publishers, Nigeria, p. 117

Odiaka, N.I. (2005). Morphological diversity among local germplasm of fluted pumpkin (Telfairia occidentalis Hook F.) collected in Makurdi, Nigeria. Journal of Food, Agriculture \& Environment, 3 (2), 199-204

Odiaka, N.I. and Akoroda, M.O. (2009). Effect of stage of fruit development and storage period on seed viability of fluted pumpkin. African Crop Science Conference Proceedings, 9, $8-86$

Odiaka, N.I., Akoroda, M.O. and Odiaka, E.C. (2008). Diversity and production methods of fluted pumpkin (Telfairia occidentalis Hook F.): Experience with vegetable farmers in Makurdi, Nigeria. African Journal of Biotechnology, 7 (8), 944-954

Ogar, E.A. and Asiegbu, J.E. (2005). Effect of fertilizer rates and cutting frequency on the marketable vegetable and fruit yields of fluted pumpkin in southern Nigeria. Agro-science, 4 (1), 66-69

Rao, V.R. (2001). Principles and concepts in plant genetic resources conservation and use. In: M.S. Saas and V.R. Rao (Eds.), Establishment and Management of Field Genebank: a Training Manual (pp. 1-16). IPGRIAPO, Sendang

RUFORUM (Regional Universities Forum for Capacity Building in Agriculture) (2010). June Monthly Brief Report on the Workshop to analyze human and institutional capacities and needs for Neglected and Underutilized Species (NUS) research and marketing Benin, Cotonou, 8-10th June 2010

Salman, T.M., Olayaki, L.A. and Oyeyemi, W.A. (2008). Aqueous extract of Telfairia occidentalis leaves reduces blood sugar and increases hematological and reproductive indices in male rats. Afr. J. Biotechnol., 7, 2299-2303

Shukla, S., Bhargava, A., Chatterjee, A., Pandey, A.C. and Mishra, B.K. (2010). Diversity in phenotypic and nutritional traits in vegetable amaranth (Amaranthus tricolor), a nutritionally underutilised crop. J Sci Food Agric., 90, 139-144 DOI 10.1002/jsfa.3797

Singh, R. and Sharma, S.K. (2007) Evaluation, maintenance, and conservation of germplasm. Advances in Botanical Research, 45 465-481

Ugese, F.D., Baiyeri, K.P. and Mbah, B.N. (2008). Effect of seed source and watering intervals on growth and dry matter yield of shea butter tree (Vitellaria paradoxa Gaertn F.) seedlings. Bio-Research, 6 (1), 303-307

Uguru, M.I. and Onovo, J.C. (2011). Evidence of polyploidy in fluted pumpkin (Telfairia occidentalis Hook F.). African J. Plant Sci., 5 (5), 287-290 